\title{
ANALISIS YURIDIS PERLINDUNGAN HUKUM TERHADAP PASANGAN PENDERITA HIV PERSPEKTIF HAK ASASI MANUSIA
}

\author{
Saivol Virdaus \\ Fakultas Hukum Universitas Islam Kadiri (UNISKA) \\ Jalan Sersan Suharmaji No.38 Kediri, Jawa Timur, Indonesia
}

\begin{abstract}
This research will describe the legal protection of the HIV-positive partner in Human Rights Perspective, which uses the Normative juridical analysis method of some positive laws in Indonesia regarding the prevention and control of HIV-AIDS Virus. In this study PLWHA (People with HIV-AIDS) and the partners are as the Subject of law Which will then be studied and analyzed using the lens of law and human rights. In this study resulted in a formula that in addition to PLWHA having the right to confidential status but to their sexual partners, PLWHA should be open and honest about their HIV status. This is in accordance with the human rights values contained in Article $28 \mathrm{H}$ paragraph (1) of the 1945 Constitution and Article 9 of Law Number 39 Year 1999 on Human Rights in order to ensure the right of security, comfort, health and the right of life of his partner. Where when there is openness then the transmission of HIV virus to the partner does not occur. although this is difficult because it has not been supported by public awareness and comprehensive understanding of the people with HIV, the government's obligation is to continue socializing and educating about HIV-AIDS in the community.
\end{abstract}

Keywords: Legal Protection, Pair of HIV Patient, Human Rights Perspective

\begin{abstract}
ABSTRAK
Penelitian ini akan mendiskripsikan tentang perlindungan hukum terhadap pasangan penderita HIV dalam perspektif Hak Asasi Manusia dimana menggunakan jenis penelitian Normatif terhadap hukum positif yang ada di Indonesia mengenai pencegahan dan penanggulangan Virus HIV-AIDS. Dalam penelitian ini ODHA (Orang Dengan HIV-AIDS ) dan Pasanganya sebagai Subjek hukum Yang selanjutnya akan dikaji dan di analisa menggunakan kacamata hukum dan hak asasi manusia. Dalam penelitian ini menghasilkan sebuah rumusan bahwa disamping ODHA memiliki Hak atas kerahasiaan statusnya akan tetapi khusus kepada pasangan seksualnya ODHA harus terbuka tentang status HIV nya. Hal ini sesuai dengan nilai-nilai Hak Asasi Manusia yang terkandung dalam Pasal $28 \mathrm{H}$ ayat (1) UUD 1945 dan Pasal 9 UU Nomor 39 Tahun 1999 tentang Hak Asasi Manusia dalam rangka menjamin hak keamanan, kenyamanan, kesehatan dan hak hidup pasanganya. Dimana ketika ada keterbukaan maka penularan virus HIV terhadap pasangan tidak terjadi. walaupun hal ini sulit karena belum didukung oleh kesadaran masyarakat dan pemahaman masyarakat secara komprehensif terhadap penderita HIV, maka kewajiban pemerintah adalah untuk terus menggalakan sosialisasi dan edukasi tentang HIV-AIDS di tengah masyarakat.
\end{abstract}

Kata kunci: Perlindungan hukum, Pasangan penderita HIV, Hak Asasi Manusia 


\section{A. PENDAHULUAN}

\section{Latar Belakang Masalah}

Data kasus penderita HIV hari semakin hari semakin bertambah dan sangat mengkhawatirkan, faktor utama penularan virus HIV masih di dominasi oleh Hubungan Seksual yang tidak aman. Data nasional yang dirilis oleh yayasan Spiritia berdasar pada data yang diperoleh dari Ditjen PP dan PL Kemenkes per september 2014 kasus HIV sebanyak 150.296 orang sementara yang sudah masuk dalam kondisi AIDS sebanyak 55.799 orang. ${ }^{61}$ ODHA (Orang Dengan HIV-AIDS) dengan segala problematikanya di tengah masyarakat masih sering mendapatkan perlakuan yang diskriminatif sehingga keterbukaan status mereka dirahasiakan demi kebaikan pasien. Kerahasiaan ini sebenarnya telah diatur dalam Pasal 57 ayat (1) UU N0 36 Tahun 2009 tentang Kesehatan "Setiap orang berhak atas rahasia kondisi kesehatan pribadinya yang telah dikemukakan kepada penyelenggara pelayanan kesehatan". 62

Kerahasiaan ini tentunya dalam rangka menjamin hak dari ODHA, hak untuk tidak mendapatkan perlakuan buruk dari masyarakat dan hak kerahasiaan atas statusnya. Hal ini menjadi bola salju didalam penanggulanan dan pecegahan penularan virus itu sendiri, dimana ketika ODHA memiliki hak untuk tidak membuka statusnya dengan pasanganya (baik kepada suami/istri maupun pasangan seksual diluar pernikahan) maka yang terjadi penularan virus HIV justru tidak bisa di hindarkan melalui hubungan seksual yang tidak aman. Kondisi masyarakat yang masih belum memahami secara komprehensif apa itu virus HIV dan Bagaimana penularanya menjadikan sikap masyarakat yang diskriminatif dan mengucilkan para penderita HIV. Paham di masyarakat yang meyakini bahwa HIV adalah penyakit kutukan

\footnotetext{
${ }^{61} \mathrm{http} / / /$ www.spiritia.or.id/Stats/StatCurr.php?lang=id\&gg=1 diakses tanggal 30 agustus 2016 jam 11.00

${ }^{62}$ Undang-Undang Republik Indonesia Nomor 36 Tahun 2009 tentang Kesehatan.
} 
karena kemaksiatan dan juga anggapan virus hiv bisa menular dengan mudah merupakan alasan kenapa masyarakat memperlakukan ODHA secara diskriminatif, kondisi ini yang menjadikan ODHA enggan terbuka dengan statusnya kepada orang lain bahkan kepada pasanganya sendiri karena dihantui rasa ketakutan akan di kucilkan, dijauhi bahkan tidak sedikit yang mendapatkan tindak kekerasan.

\section{Rumusan Masalah}

Bagaimana perlindungan hukum pasangan Penderita HIV yang terancam tertular dengan ketidakterbukaan pasangan baik suami ataupun istri ditinjau dari Hak Asasi Manusia.

\section{Tujuan Penelitian}

Untuk mengkaji secara mendalam perlindungan hukum pasangan Penderita HIV yang terancam tertular dengan ketidakterbukaan pasangan baik suami ataupun istri ditinjau dari Hak Asasi Manusia.

\section{B. PEMBAHASAN}

\section{Human Immunodeficiency Virus (HIV)}

HIV merupakan akronim dari Human Immunodeficiency Virus yang artinya adalah sebuah Virus yang menyerang kekebalan tubuh manusia. Sementara AIDS adalah Acquired Immune Deficiency Syndrome yaitu kumpulan gejala akibat kekurangan atau kelemahan sistem kekebalan tubuh yang dibentuk setelah kita lahir yang di sebabkan oleh virus HIV. Jadi pada dasaranya HIV berbeda dengan AIDS, HIV adalah virusnya sementara AIDS adalah sebuah kondisi yang disebabkan karena virus HIV. ${ }^{63}$ Jelasna seseorang tidak akan terkena AIDS jika tidak terinveksi virus HIV. Banyak pemahaman yang keliru ditengah masyarakat bahwa HIV AIDS dengan mudah meluar lewat udara, pekaian atau peralatan yang digunakan bersama. HIV hanya bisa

\footnotetext{
${ }^{63}$ Spritia, Hidup dengan HIV-AIDS, (Yayasan Spiritia, 2009), hlm. 7
} 
hidup dalam cairan tubuh, yaitu, darah, air mani, cairan vagina dan air susu ibu. Sehingga Virus ini hanya bisa menular melalui aktivitas transfusi darah, penggunaan jarum suntik yang bergantian, hubungan seksual yang tidak aman dan penularan dari ibu positif ke anak melalui ASI. HIV tidak menular melalui aktivitas sosial seperti bersalaman, memakai peralatan rumah tangga bersamaan seperti alat makan, telepon, kamar mandi, WC, kamar tidur, gigitan nyamuk, Memakai fasilitas umum bersamaan misalnya kolam renang dan lain-lain. Bahkan HIV tidak menular hanya melalui tidur bersama dan berciuman selama tidak terjadi masuknya cairan tubuh yang disebutkan diatas dari orang yang positif HIV ke tubuh orang lain.

Orang yang positif terinveksi virus HIV diebut sebagai ODHA (Orang Dengan HIV-AIDS). Masyarakat Indonesia melihat sebelah mata tentang ODHA, pehamaman masyarakat yang kurang komprehensif tentang HIV menjadikan masyarakat bersikap diskriminatif terhadap ODHA. Sering kali masyarakat meyakini bahwa HIV adalah penyakit kutukan karena perbuatan zina dan pemahaman bagaiamana HIV menular tidak dipahami oleh masyarakat menjadikan mereka bersikap menjauhi, takut dan mengucilkan. Kondisi sosial masyarakat yang seperti ini menjadikan ODHA takut untuk terbuka statusnya walaupun dengan orang terdekat seperti istri, suami dan keluarganya. Ini menjadikan persolan sendiri di dalam upaya pencegahan penularan Virus HIV karena orang yang terinfeksi virus HIV sebelum memasuki fase AIDS tidak bisa dilihat ciri-cirinya secara fisik. Oleh karena itu kondisi sosial yang kondusif, pemahaman masyarakat yang komprehensif sangat berperan penting dalam suksesnya pencegahan penularan.

Sejarah tentang HIV/AIDS dimulai ketika tahun 1979 di Amerika Serikat ditemukan seorang gay muda dengan Pneumocystis Carinii dan dua orang gay muda dengan Sarcoma Kaposi. Pada tahun 1981 ditemukan seorang gay muda dengan kerusakan sistem kekebalan tubuh. Di Amerika Utara dan Inggris, epidemik pertama terjadi pada kelompok laki-laki homoseksual, 
selanjutnya pada saat ini epidemik terjadi juga pada pengguna obat dan pada populasi heteroseksual. ${ }^{64}$

Menurut catatan sejarah di Indonesia, HIV pertama kali dilaporkan di Bali pada bulan April 1987, terjadi pada orang berkebangsaan Belanda. Babak baru kasus HIV di Indonesia dimulai, seiring dengan bertambahnya waktu kasus HIV semakin bertambah melaui media penularan yang salah satunya adalah Hubungan seksual yang tidak aman. Pengidap HIV yang tidak bisa dilihat ciri-ciri secara fisik ini menjadikan pencegahan penularan HIV sulit di tekan. Dimana status virus HIV hanya bisa diketahui melalui test darah, sementara didukung dengan lemahnya kesadaran masyarakat untuk memeriksakan diri menjadi penyebab utama penularan HIV. Di Indonesia penemuan kasus HIV dari hari kehari terus mengalami peningkatan dan penambahan. Dengan adanya program penanggulangan HIV di indonesia menjadi salah satu pemicu naiknya data penderita HIV karena dengan program itu kasus demi kasus bisa terus terungkap dengan di masifkanya program-program test HIV dan sosialisasi tentang virus HIV-AIDS. Data kasus HIV yang dirilis oleh Yayasan Spritia yang bersumber dari data kasus Ditjen PP\&PL Kemenkes pada tahun 2014 menunjukan Provinsi Papua menempati urutan pertama dan Jawa timur menempati posisi urutan kedua terbanyak kasus akumulatif HIV di Indonesia.

\footnotetext{
${ }^{64}$ https://stophivafkmundip.wordpress.com/2014/03/29/sejarah-hivaids-di-dunia-dan-indonesia/ diakses tanggal 08 september 2016 jam 12:00
} 


\begin{tabular}{|c|c|c|c|}
\hline No. & |Provinsi/Province & HIV & AlDS \\
\hline 1 & Papua & 16,051 & 10,184 \\
\hline 2 & Jawa Timur/East Java & 19,249 & 8,976 \\
\hline 3 & DKI Jakarta & 32,782 & 7,477 \\
\hline 4 & Bali & 9,637 & 4,261 \\
\hline 5 & Jawa Barat/West Java & 13,507 & 4,191 \\
\hline 6 & Jawa Tengah/Central Java & 9,032 & 3,767 \\
\hline 7 & Papua Barat/West Papua & 2,714 & 1,734 \\
\hline 8 & Sulawesi Selatan/South Sulawesi & 4,314 & 1,703 \\
\hline 9 & Kalimantan Barat/West Kalimantan & 4,574 & 1,699 \\
\hline 10 & Sumatera Utara/North Sumatra & 9,219 & 1,573 \\
\hline 11 & Riau & 2,050 & 1,104 \\
\hline 12 & Banten & 3,642 & 1,042 \\
\hline 13 & Sumatera Barat/West Sumatra & 1,136 & 952 \\
\hline 14 & DI Yogyakarta/Jogiakarta & 2,611 & 916 \\
\hline 15 & Sulawesi Utara/North Sulawesi & 2,312 & 798 \\
\hline 16 & Maluku/Moluccas & 1,456 & 527 \\
\hline 17 & Nusatenggara Timur/East Nusa Tenggara & 1,751 & 496 \\
\hline 18 & Nusatenggara Barat/West Nusa Tenggara & 812 & 490 \\
\hline 19 & Jambi & 751 & 458 \\
\hline 20 & Lampung & 1,090 & 423 \\
\hline 21 & Sumatera Selatan/South Sumatra & 1,652 & 409 \\
\hline 22 & Kepulauan Riau/Riau Archipelago & 4,555 & 382 \\
\hline 23 & Kalimantan Selatan/South Kalimantan & 526 & 364 \\
\hline 24 & Kalimantan Timur/East Kalimantan & 2,541 & 332 \\
\hline 25 & Bangka Belitung & 510 & 319 \\
\hline 26 & Sulawesi Tenggara/SE Sulawesi & 330 & 266 \\
\hline 27 & Sulawesi Tengah/Central Sulawesi & 404 & 257 \\
\hline 28 & NAD/Aceh & 162 & 193 \\
\hline 29 & Maluku Utara/North Moluccas & 247 & 165 \\
\hline 30 & Bengkulu & 308 & 160 \\
\hline 31 & Kalimantan Tengah/Central Kalimantan & 253 & 107 \\
\hline 32 & Gorontalo & 68 & 68 \\
\hline 33 & Sulawesi Barat/West Sulawesi & 39 & 6 \\
\hline & Jumlah/Total & 150,285 & 55,799 \\
\hline
\end{tabular}

Data diambil dari webs Yayasan Spiritia yang bersumber dari data akumulasi kasus Ditjen PP\&PL Kemenkes tahun 2014

\section{Perlindungan Hukum Pasangan Penderita HIV.}

Fitzgerald menjelaskan teori pelindungan hukum Salmond bahwa hukum bertujuan mengintegrasikan dan mengkoordinasikan berbagai kepentingan dalam masyarakat karena dalam suatu lalu lintas kepentingan, perlindungan terhadap kepentingan tertentu hanya dapat dilakukan dengan cara membatasi berbagai kepentingan di lain pihak. ${ }^{65}$

${ }^{65}$ Satijipto Raharjo, Ilmu Hukum, (Bandung: PT. Citra Aditya Bakti, 2000), hlm. 53 
Kepentingan hukum adalah mengurusi hak dan kepentingan manusia, sehingga hukum memiliki otoritas tertinggi untuk menentukan kepentingan manusia yang perlu diatur dan dilindungi. ${ }^{66}$

Perlindungan hukum harus melihat tahapan yakni perlindungan hukum lahir dari suatu ketentuan hukum dan segala peraturan hukum yang diberikan oleh masyarakat yang pada dasarnya merupakan kesepakatan masyarakat tersebut untuk mengatur hubungan prilaku antara anggota-anggota masyarakat dan antara perseoranan dengan pemerintah yang dianggap mewakili kepentingan masyarakat.

Menurut Satijipto Raharjo, perlindungan hukum adalah memberikan pengayoman terhadap hak asasi manusia (HAM) yang dirugikan orang lain dan perlindungan itu di berikan kepada masyarakat agar dapat menikmati semua hak-hak yang diberikan oleh hukum. ${ }^{67}$ Keberadaan hukum yang memiliki fungsi sebagai protektor menjadikan instrumen utama dalam rangka menjamin dan melindungi Hak Asasi Manusia. Hak hidup dan hak mendapatkan jaminan kesehatan merupakan Hak dasar yang harus dilindungi oleh negara melalui hukum positif yang ada, sedangkan yang terjadi saat ini adalah masih terjadi kekosongan hukum didalam perlindungan terhadap pasangan pengidap HIV, sehingga mereka belum terlindungi. Menurut lili rasjidi dan I.B Wysa Putra berpendapat bahwa hukum dapat difungsikan untuk mewujudkan perlindungan yang sifatnya tidak sekedar adaptif dan fleksibel, melainkan juga prediktif dan antisipatif. ${ }^{68}$ Pendapat Sunaryati Hartono mengatakan bahwa hukum dibutuhkan untuk mereka yang lemah dan belum kuat secara sosial, ekonomi dan politik untuk memperoleh keadilan

\footnotetext{
${ }^{66}$ Ibid, hlm. 69

${ }^{67}$ Ibid, hlm. 54

${ }^{68}$ Lili Rasjidi dan I.B Wysa Putra, Hukum Sebagai Suatu Sistem, (Bandung, Remaja
} Rusdakarya, 1993), hlm. 118 
social. ${ }^{69}$ Kondisi hari ini pasangan penderita HIV masih belum terlindungi atas kesehatan dan keamananya. Pemahaman masyarakat yang sepotongpotong tentang virus HIV dan Penularanya menjadikan stigma negatif bagi penderita HIV dan AIDS. Banyak sekali kasus stigma dan diskriminasi yang diterima oleh penderita HIV-AIDS ketika statusnya bocor dan di ketahui masyarakat. Perlakuan buruk yang diterima menjadikan mereka para penderita HIV takut dan enggan terbuka dengan statusnya baik kepada saudara atau bahkan kepada pasanganya.

Kondisi seperti ini menjadikan pasangan seksual dari penderita terancam kesehatanya. Sudah bisa dipastikan pasanganya akan tertular virus HIV karena salah satu media penularan virus HIV adalah melalui Hubungan Seksual yang tidak aman (Tidak menggunakan Kondom). ${ }^{70}$ Penderita HIV tidak memiliki ciri-ciri fisik apapun dengan kata lain sama persis dengan orang sehat biasa dan hanya bisa diketahui hanya dengan melalu test darah, kecuali bagi penderita yang sudah masuk di fase AIDS. ${ }^{71}$ Hal ini jika penderita HIV tidak terbuka dengan statusnya maka pasanganya tidak akan tau kalau istri / suaminya terpapar HIV. Dilhat dari kacamata hukum dan Hak Asasi Manusia maka dengan melihat kondisi seperti ini perlu dilakukan perlindungan hukum terhadap pasangan penderita HIV dalam rangka untuk menjamin hak kesehatan dan kelangsungan hidupnya.

\section{Perspektif Hak Asasi Manusia}

Pada dasarnya setiap manusia terlahir sebagai makhluk ciptaan Tuhan Yang Maha Esa yang secara kodrati mendapatkan hak dasar yaitu kebebasan, hak hidup, hak untuk dilindungi, dan hak yang lainnya. Hal ini senada dengan prinsip hukum alam pada abad ke-18 yaitu kebebasan individu dan keutamaan rasio, salah satu penganutnya adalah Locke, menurut Locke teori hukum

${ }^{69}$ Sunaryati Hartono, Politik Hukum Menuju Satu Sistem Hukum Nasional, (Bandung: Alumni, 1991), hlm. 55

${ }^{70}$ PPPL Kemenkes, ANDA \& HIV, AIDS,IMS, (Jakarta 2008), hlm. 09

${ }^{71} \mathrm{http}: / /$ pkbi-diy.info/?page_id=3546 diakses tanggal 30 Agustus 2016 jam 20:00 
beranjak dari dua hal di atas yaitu kebebasan individu dan keutamaan rasio. Ia juga mengajarkan pada kontrak sosial.

Menurutnya manusia yang melakukan kontrak sosial adalah manusia yang tertib dan menghargai kebebasan, hak hidup dan pemilikan harta sebagai hak bawaan manusia. Menurut Locke masyarakat yang ideal adalah masyarakat yang tidak melanggar hak-hak dasar manusia.

Menurut locke, hak-hak tersebut tidak ikut diserahkan kepada penguasa ketika kontrak sosial dilakukan. Oleh karena itu, kekuasaan penguasa yang diberikan lewat kontrak sosial, dengan sendirinya tidak mungkin bersifat mutlak. Kalau begitu, adanya kekuasaan tersebut justru untuk melindungi hak-hak kodrat dimaksud dari bahaya-bahaya yang mungkin mengancam, baik datang dari dalam maupun dair luar. Begitulah, hukum yang dibuat dalam negara pun bertugas melindungi hak-hak dasar tersebut. Hak-hak dasar yang biasa disebut sebagai hak asasi, tanpa perbedaan antara satu dengan lainnya. Dengan hak asasi tersebut, manusia dapat mengembangkan diri pribadi, peranan, dan sumbangannya bagi kesejahteraan hidup manusia.

Pemikiran yang lebih eksplisit tentang hukum sebagai pelindung hakhak asasi dan kebebasan warganya, dikemukakan oleh Immanuel Kant. Bagi Kant, manusia merupakan makhluk berakal dan berkehendak bebas. Negara bertugas menegakkan hak-hak dan kebebasan warganya. Kemakmuran dan kebahagian rakyat merupakan tujuan negara dan hukum, oleh karena itu, hakhak dasar itu, tidak boleh dihalangi oleh Negara.

Hak-hak dasar yang melekat pada diri manusia secara kodrati, universal, dan abadi sebagai anugerah Tuhan Yang Maha Esa, meliputi hak untuk hidup, hak berkeluarga, hak mengembangkan diri, hak keadilan, hak kemerdekaan, hak berkomunikasi, hak keamanan, dan hak kesejahteraan, yang oleh karena itu tidak boleh diabaikan atau dirampas oleh siapapun. 
Menyinggung hak keamanan pada diri setiap individu, pada pasal-pasal HAM ayat (7) menjelaskan setiap manusia di depan hukum berhak untuk mendapatkan perlindungan dari hukum yang sama tanpa diskriminasi. Semua berhak atas perlindungan yang sama terhadap setiap bentuk diskriminasi yang bertentangan dengan pernyataan ini dan terhadap segala hasutan yang mengarah pada diskriminasi semacam itu.

Berdasarkan regulasi yang ada dilihat dari kacamata Hak Asasi Manusia baru Penderita HIV saja yang dijamin Haknya atas kerahasiaan statusnya. Hal ini tersurat dalam Pasal 57 ayat (1) Undang-undang Nomor 36 Tahun 2009 tentang Kesehatan. Namun untuk pasangan penderita HIV Cenderung menjadi korban dengan adanya hak kerahasiaan ini. Hak yang dimiliki penderita HIV yaitu Hak Kerahasiaan atas statusnya berbenturan dengan Hak orang lain dan justru Hak orang lain ini menjjadi lebih fundamental melihat resikonya bisa menularkan ke pasangan dan bisa menular juga ke anaknya jika hamil hasil hubungan Seksual yang tidak aman antara penderita HIV dan pasanganya. Hak untuk tahu dan mengetahui status pasangan seksual ini menjadi urgen melihat resikonya. Sehingga hak kerahaisaan yang dimiliki oleh penderita HIV menjadi hilang demi kepentingan yang lebih yatu hak kesehatan pasangan agar tidak tertular.

"Right to Know. Although confidentiality is critical in both health care and public health, it may at times conflict with other legal and ethical claims. Many scholars treat the right to confidentiality as pliable when its protection poses a significant risk of serious injury to others ",72

Di dalam teory Hak Asasi Manusia selain dikenal dengan Teory absolut muncul anti tesa yatu Cultural Relativism Theory atau Teori Relativisme Budaya. Gagasan tentang relativisme budaya Mendalilkan bahwa kebudayaan merupakan satu-satunya sumber keabsahan hak atau kaidah moral. Karena itu

\footnotetext{
${ }^{72}$ Lawrance O. Gostin and Ziita Lazzarini, Human Rights and Public Health in The AIDS Pandemic, (Oxford University Press 1997), hlm. 17
} 
hak asasi manusia dianggap perlu dipahami dari konteks kebudayaan masingmasing negara. Semua kebudayaan mempunyai hak hidup serta martabat yang sama yang harus dihormati. Berdasarkan dalil ini, para pembela gagasan relativisme budaya menolak universalisasi hak asasi manusia, apalagi bila ia didominasi oleh satu budaya tertentu. ${ }^{73}$ Melihat dari teori relativisme budaya bisa diartikan bahwa tidak ada Hak yang absolut dan tidak bisa dibatasi, Hak Asasi manusia bisa dibatasi akan tetapi semata-mata untuk menjamin Hak Orang lain.

Ketentuan UUD 1945 yang menyatakan bahwa hak asasi manusia dapat dibatasi juga diperkuat oleh penempatan Pasal 28J sebagai pasal penutup dari seluruh ketentuan yang mengatur tentang hak asasi manusia dalam Bab XA UUD 1945 yaitu :

a. Setiap orang wajib menghormati hak asasi manusia orang lain dalam tertib kehidupan bermasyarakat, berbangsa, dan bernegara.

b. Dalam menjalankan hak dan kebebasannya, setiap orang wajib tunduk kepada pembatasan yang ditetapkan dengan undangundang dengan maksud semata-mata untuk menjamin pengakuan serta penghormatan atas hak dan kebebasan orang lain dan untuk memenuhi tuntutan yang adil sesuai dengan pertimbangan moral, nilai-nilai agama, keamanan, dan ketertiban umum dalam suatu masyarakat demokratis. $^{74}$

Hal ini sejalan juga dengan sistematika pengaturan dalam Universal Declaration of Human Rights yang juga menempatkan pasal tentang pembatasan hak asasi manusia sebagai pasal penutup, yaitu Pasal 29 ayat (2) yang berbunyi :

\footnotetext{
${ }^{73}$ PUSHAM UII, Hukum Hak Asasi Manusia, (Yogyakarta 2008) hlm. 20

${ }^{74}$ Pasal 28 J ayat (1) dan (2) Undang-Undang Dasar Republik Indonesia Tahun 1945
} 
"In the exercise of his rights and freedoms, everyone shall be subject only to such limitations as are determined by law solely for the purpose of securing due recognition and respect for the rights and freedoms of others and of meeting the just requirements of morality, public order and the general welfare in a democratic society. ",75

Melihat dari ketentuan Hak Asasi Manusia yang ada di UUD I945 dan UDHR dapat ditarik relevansinya bahwa Hak atas kerahasiaan yang dimiliki oleh Penderita HIV luntur demi menjamin Hak fundamental yaitu hak Kesehatan dan Kehidupan pasanganya bahkan keturunanya. Dengan Demikian Penderita HIV memiliki kewajiban dan harus membuka status HIV nya kepada Pasangan Seksualnya untuk menghindari penularan virus HIV melalui hubungan seksual yang tidak aman. Dengam keterbukaan ini maka Hubungan Seksual bisa dilakukan dengan aman yakni dengan program penggunaan Kondom untuk menghindari penularan virus.

Hal ini sesuai dengan nilai-nilai Hak Asasi Manusia yang terkandung dalam Pasal 28 H ayat (1) UUD 1945 yang berbunyi : "Setiap orang berhak hidup sejahtera lahir dan batin, bertempat tinggal, dan mendapatkan lingkungan hidup yang baik dan sehat serta berhak memperoleh pelayanan kesehatan." Serta Pasal 9 UU Nomor 39 Tahun 1999 tentang Hak Asasi Manusia yang berbunyi : "Dalam rangka menjamin Hak keamanan, kenyamanan, kesehatan dan hak hidup pasanganya. Dimana ketika ada keterbukaan maka penularan virus HIV terhadap pasangan tidak terjadi. walaupun hal ini sulit karena belum didukung oleh kesadaran masyarakat dan pemahaman masyarakat secara komprehensif terhadap penderita HIV, maka kewajiban pemerintah adalah untuk terus menggalakan sosialisasi dan edukasi tentang HIV-AIDS di tengah masyarakat.

\footnotetext{
${ }^{75}$ Pasal 29 ayat (2), Universal Declaration of Human Rights
} 


\section{PENUTUP}

\section{Kesimpulan}

a. Perlindungan Hukum terhadap orang yang Tertular Virus HIV dari pasangannya sesuai hukum yang berlaku di Indonesia belum optimal. Belum ada Undang-undang atau peraturan khusus yang komprehensif mengatur perlindungan hukum terhadap orang yang tertular virus HIV.

b. Berdasakan perspektif Hak Asasi Manusia, maka antara orang dengan HIV-AIDS (ODHA) dan pasanganya memiliki hak yang sama untuk mendapatkan perlindungan dan jaminan atas hak hidup dan hak kesehatannya. Sehingga ODHA wajib memberitahu dan terbuka terhadap pasanganya terkait virus yang di deritanya agar ketika melakukan hubungan sexsual bisa dicegah penularan Virusnya. 


\section{DAFTAR PUSTAKA}

\section{A. Peraturan Perundang-undangan}

Undang-Undang Dasar Republik Indonesia Tahun 1945

Universal Declaration of Human Rights

\section{B. Literatur}

Raharjo, Satijipto, Ilmu Hukum, Bandung: PT. Citra Aditya Bakti, 2000.

Lili Rasjidi dan I.B Wysa Putra, Hukum Sebagai Suatu Sistem, Bandung, Remaja Rusdakarya, 1993.

Hartono, Sunaryati, Politik Hukum Menuju Satu Sistem Hukum Nasional, Bandung: Alumni, 1991.

Lawrance O. Gostin and Ziita Lazzarini, Human Rights and Public Health in The AIDS Pandemic, (Oxford University Press 1997.

PUSHAM UII, Hukum Hak Asasi Manusia, Yogyakarta, 2008. PPPL Kemenkes, ANDA \& HIV, AIDS,IMS, Jakarta, 2008. 